BAKTIMAS

Jurnal Pengabdian pada Masyarakat
Vol. 1, No. 3,

Oktober 2019
eISSN 2685-113x

pISSN 2685-0303

\title{
Pelatihan Pembuatan Nugget dengan Penambahan Sayuran di Panti Asuhan Yayasan Islam Media Kasih Banda Aceh
}

\author{
Fadlan Hidayat $^{1 *}$, Salfauqi Nurman ${ }^{2}$, Ruka Yulia $^{1}$, Dewi Ermaya ${ }^{1}$ \\ ${ }^{1}$ Program Studi Teknologi Pangan, Fakultas Teknologi Pertanian, Universitas Serambi Mekkah \\ ${ }^{2}$ Program Studi Teknologi Industri Pertanian, Fakultas Teknologi Pertanian, Universitas Serambi \\ Mekkah \\ Jl. Unmuha, Batoh, Banda Aceh, kode pos 23245 \\ *penulis korespodensi: fadlanhidayat@serambimekkah.ac.id \\ http://dx.doi.org/10.32672/btm.v1i3.1425
}

\begin{abstract}
Abstrak
Pembuatan nugget dengan penambahan sayuran di Panti Asuhan Yayasan Islam Media Kasih Gampong Seutui Kecamatan Baiturrahman Kota Banda Aceh memberikan informasi terkait tentang cara pengelohan produk pangan yang dapat diimplementasikan atau dilakukan oleh anak-anak panti. Kegiatan ini dilakukan pada hari senin, 12 Februari 2018, Peserta kegiatan ini adalah anakanak Panti Asuhan yang berjumlah \pm 20 orang. Kegiatan ini bertujuan memberikan pemahaman terhadap produk pengolahan pangan yaitu pembuatan nugget dengan penambahan sayuran. Manfaat dari kegiatan ini yaitu anak-anak panti asuhan dapat mengolah produk pangan rumah tangga dan produk hasil pertanian lainnya secara mandiri.
\end{abstract}

Kata Kunci: Pembuatan, Nugget, Panti Asuhan

\section{Abstract}

Training of making nugget with the addition of vegetables in Orphanage of Islam Media kasih Foundation Banda Aceh. Making nugget with the addition of vegetables at the Orphanage of Media Kasih Islamic Foundation in Seutui Village Baiturrahman Sub-distric, Banda Aceh City, provided related information on how to process of food products that could be implemented or done by the orphans. This activity was conducted on Monday, February 12, 2018. The participants of this activity are orphans around 20 children. The aims of this activity was to give an information about processing food products such as vegetables nugget. The benefits from this activity were the orphans be able to processed household food products and other agricultural products independently.

Keywords : Making, Nugget, Orphanage

\section{PENDAHULUAN}

Pengolahan dalam bidang pangan saat ini semakin berkembang dalam menghasilkan produk-produk olahan. Beberapa produk olahan yang disukai oleh konsumen yaitu nugget. Nugget yaitu produk olahan yang direstrukrisasi dengan adonan dan pelapis untuk mempertahankan kualitas. ( Lukman dkk, 2009). 
Nugget adalah suatu bentuk produk olahan daging yang terbuat dari daging giling yang dicetak dalam bentuk potongan empat persegi dan dilapisi dengan tepung berbumbu (battered dan braded) (Maghfiroh, 2000). Nugget merupakan salah satu bentuk produk makanan beku siap saji, yaitu produk yang telah engalami pemanasan sampai setengah matang (precooked), kemudian dibekukan (Afrisanti, 2010).

Sekarang ini, gaya hidup modern yang semuanya serba praktis dan kemajuan teknologi yang pesat seringkali membuat kita mengkonsumsi makanan yang praktis penyajiannya. Hal ini juga disebabkan karena padatnya kegiatan dan kesibukan kita yang dijalani. Makanan siap saji pun akhirnya menjadi pilihan pertama yang dipilih disaat kita sedang lapar ditengah menjalani kesibukan, dikarenakan penyajiannya yang praktis dan sekaligus memiliki rasa yang enak menurut selera banyak orang.

Namun tidak semua orang menyukai sayuran, dikarenakan menurut sebagian orang tersebut rasa yang dimilki sayuran "aneh" ataupun tekstur dan bau yang tidak disukai. Oleh karena itu, kami membuat nugget dengan penambahan sayuran yang memberikan alternatif dalam membantu memenuhi kebutuhan tubuh yang sangat besar yang mungkin masih belum terpenuhi melalui makanan yang dikonsumsi.

Menurut Evanuarini dan Purnomo (2011) nugget sangat disukai oleh masyarakat terutama anak-anak, banyak dipasaran produk nugget yang mempunyai merek-merek yang berbeda, selain dibuat dari daging nugget juga dapat dibuat dengan vegetarian. Dengan pembuatan dengan vegetarian merupakan salah satu alternatif meningkatkan minat pata konsumen terutama anak-anak yang tidak menyukai sayur-sayuran.

Produk olahan nugget juga menjadi pilihan tersendiri untuk para konsumen vegetarian. Produk olahan ini sangat bergizi karena di dalam sayur-sayuran banyak terdapat zat gizi seperti vitamin dan mineral (Alamsyah, 2007).

\section{Bahan dan alat}

\section{BAHAN DAN METODE}

Bahan yang digunakan dalam pembuatan nugget dengan penambahan sayuran adalah ikan, wortel, bawang putih, bawang merah, kemiri, gula, garam, daun bawang, tepung terigu, merica, bubuk, air.

Alat yang digunakan adalah blender, loyang, dandang, pisau, telenan, baskom.

\section{Metode}

Pengabdian kepada masyarakat ini dilakukan oleh tim Fakultas Teknologi Pertanian dan dibantu oleh beberapa mahasiswa bermitra dengan Panti Asuhan Media Kasih di Gampong Seutui Kecamatan Baiturrahman Kota Banda Aceh, kegiatan yang dilakukan meliputi penyuluhan tentang pengolahan produk makanan rumah tangga dan pengolahan nugget serta praktek pembuatan nugget dengan penambahan sayuran.

Penyuluhan yang dilakukan dengan memberi informasi mengenai pengolahan produk makanan rumah tangga secara mandiri dan memberikan informasi bagaimana cara pengolahan daging menjadi makanan yang menarik seperti nugget. Selain daging nugget juga dapat diolah dari bahan sayuran dan buah-buahan. Nugget juga bisa divariasikan dengan penambahan sayuran.

Praktek pembuatan nugget dilakukan di Panti Asuhan Media Kasih yang dipraktekkan langsung oleh anak-anak panti asuhan yang dipandu tim pelaksana, hal 
BAKTIMAS

Jurnal Pengabdian pada Masyarakat
Vol. 1, No. 3,

Oktober 2019
eISSN 2685-113x

pISSN 2685-0303

tersebut direspon positif sehingga mereka sangat antusias dalam melaksanakan kegiatan ini, nugget yang dibuat yaitu nugget dengan penambahan sayur wortel.

\section{HASIL DAN PEMBAHASAN}

Kegiatan pengabdian kepada masyarakat dilakukan di Panti Asuhan Media Kasih di Gampong Seutui Kecamatan Baiturrahman Kota banda Aceh. Beberapa materi yang disampaikan pada kegiatan tersebut antara lain :

1. Penyuluhan mengenai pengolahan produk rumah tangga dan pengolahan nugget.

2. Praktek langsung pembuatan nugget dengan penambahan sayuran.

Selama kegiatan penyuluhan di Panti Asuhan tersebut anak-anak panti sangat antusias dalam menyerap materi yang disampaikan. Hal ini terlihat dari banyaknya anak-anak panti yang hadir dalam kegiatan tersebut serta banyaknya meraka yang bertanya dan berdiskusi dengan tim pelaksana kegiatan. Isi materi yang disampaikan dalam kegiatan tersebut diantaranya yaitu pengolahan produk rumah tangga dan pengolahan nugget secara mandiri.

Dalam pembuatan nugget, bahan pengisi dan bahan dasar menentukan karakterisitik nugget yang dihasilkan. Biasanya digunakan bahan dasar berupa daging ayam, ikan, udang, selain bahan tersebut juga dapat dilakukan dengan penambahan sayuran. Penambah sayuran menjadi nugget vegetarian menjadi salah satu alternatif bagi yang tidak suka mengkonsumsi sayuran dan juga cukup baik dalam pemenuhan gizi dalam kehidupan sehari-hari. Diharapkan dengan adanya pengolahan nugget dengan penambahan sayuran dapat menumbuhkan minat mengkonsumsi nugget terutama anak-anak dan para pembinat sayur-sayuran (Rohaya dkk, 2013).

Anak-anak panti asuhan sangat merespon kegiatan tersebut. Dari beberapa bahan tersebut kemudian disepakati bahan yang digunakan untuk membuat nugget dengan penambahan sayuran, bahan tersebut adalah ikan sebagai bahan utama dan sayur yang ditambahkan yaitu wortel. Hal tersebut dipilih karena bahan nya yang mudah didapat di lingkungan sekitar panti asuhan.

Kegiatan yang kedua yaitu memperaktekkan langsung cara pengolahan nugget dengan penambahan. Kegiatan praktek dilakukan oleh anak-anak panti asuhan dengan arahan dari tim pelaksana kegiatan. Sesuai dengan kesepakatan pada saat penyampaian materi pelatihan tentang pembuatan nugget dengan penambahan sayuran maka dilakukan praktek pembuatan nugget dengan penambahan sayuran (Rujiah, 2013).

Selanjutnya kita berharap pelatihan seperti dapat berkelanjutan, kegiatan pembuatan nugget dengan penambahan sayuran dapat dilihat pada gambar dibawah ini 


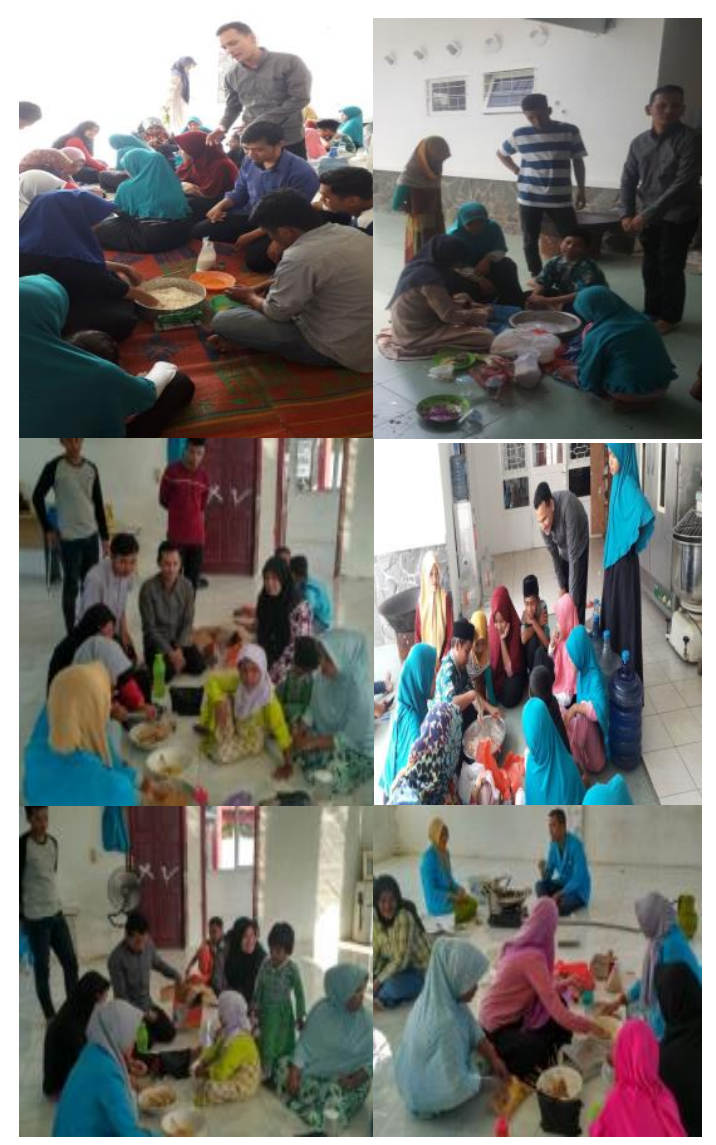

Gambar 1. Proses pelatihan pembuatan nugget.

\section{KESIMPULAN}

Berdasarkan pengabdian yang telah dilakukan dapat disimpulkan bahwa, Kerjasama pengabdian kepada masyarakat antara Tim Pelaksana kegiatan dari Fakultas Teknologi Pertanian dan Panti Asuhan Media Kasih sangat antusias dalam mengikuti kegiatan tersebut. Anak-anak panti asuhan sudah bisa mempraktekkan cara pembuatan. Dengan adanya kegiatan seperti ini diharapkan anak-anak panti asuhan dapat mengolah produk rumah tangga dan produk hasil pertanian lainnya secara mandiri.

\section{DAFTAR PUSTAKA}

Afrisanti, D.W. 2010. Kualitas Kimia dan Organoleptik Nugget Daging Kelinci dengan Penambahan Tepung Tempe. Skripsi. Program Studi Peternakan. Fakultas Pertanian. Surakarta : Universitas Sebelas Maret.

Alamsyah, Y. 2007. Anek Nugget Sehat Nan Lezat. Agro Media, Jakarta. 
BAKTIMAS

Jurnal Pengabdian pada Masyarakat
Vol. 1, No. 3,

Oktober 2019
eISSN 2685-113x

pISSN 2685-0303

Evanuarini, H, \& Purnomo, H. 2011. Physical and Organoleptic Quality Of Chicken Nuggets Fried at Different Temperature and Time. Journal of Agriculture and Food Technology, 1(8), 133-136.

Lukman I., Huda, N., \& Ismail, N. 2009. Physicochemical and sensory properties of commercial chicken nuggets. Asian Journal of Food and Agro-Industry, 2(2), 171-180.

Maghfiroh, I. 2000. Pengaruh Penambahan Bahan Pengikat Terhadap Karaktristik Nugget dari Ikan Patin (Pangasius hypothalamus). Skripsi. Program Studi Teknologi Hasil Perikanan, Fakultas Perikanan Institut Pertanian Bogor, Bogor.

Rohaya, S., Husna, N. L., \& Bariah, K (2013). Penggunaan Bahan Pengisi Terhadap Mutu Nugget Vegetarian Berbahan Dasar Tahu dan Tempe. Jurnal Teknologi dan Industri Pertanian Indonesia, vol 5(1), 7-16.

Rujiah., Ninsix, R., \& Hayati, Z (2013). Pengolahan Nugget Sayur. Jurnal Teknologi Pertanian, vol. 2(1), 35-47. 